\title{
A Strategic E-Marketing Framework For Sport Mega-Events
}

\author{
Paul S. Radikonyana, Ph.D., University of Pretoria, South Africa \\ Ernie Heath, PhD., University of Pretoria, South Africa \\ Felicité Fairer-Wessels, Ph.D., University of Pretoria, South Africa \\ J.J. Prinsloo, Ph.D., North-West University, South Africa \\ Theuns G. Pelser, Ph.D., University of KwaZulu-Natal, South Africa
}

\begin{abstract}
This article reports on a study that was conducted which aims to understand the optimal usage of e-marketing in sport mega-events with reference to the 2010 FIFA Soccer World Cup ${ }^{T M}$ which was held in South Africa. A conceptual framework to optimally leverage e-marketing opportunities related to the hosting of sport mega-events was developed from the findings of this study. Building on an in-depth analysis of the contemporary literature on this very dynamic topic, as well as key lessons learned from an analysis of international case studies, primary research was conducted before and after the 2010 FIFA Soccer World Cup ${ }^{T M}$, involving key stakeholders in the event and destination marketing sphere. Based on the preceding phases, the strategic framework that was conceptualised provides parameters and guidelines for the effective utilisation of e-marketing and e-marketing tools in future sport mega-events. Furthermore, 11 critical success factors (CSFs) were determined that should be considered when developing and implementing an e-marketing strategy for mega-events. In addition to adding value to the body of knowledge in this increasingly important sphere of tourism, recommendations regarding future research in this dynamic field of study are addressed.
\end{abstract}

Keywords: E-Marketing; Mega-Events; Olympic Games; FIFA Soccer World Cup

\section{INTRODUCTION}

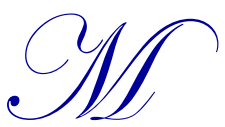

ega-events such as the Olympic Games and the FIFA Soccer World Cups ${ }^{\mathrm{TM}}$ (FSWC $\left.{ }^{\mathrm{TM}}\right)$ are generally initiated and driven by cadres of societal elites, and are aimed at satisfying development goals around competitiveness (Pillay \& Bass, 2008; Hachleitner \& Manzenreiter, 2010). It is therefore not surprising that host cities invest considerably on improving sporting facilities and supporting infrastructure to enhance the potential for purported economic profits associated with hosting of sport mega-events (Kavetsos \& Szymanski, 2010; Konstantaki \& Wickens, 20108).

The hosting of mega-events has become a growth industry all over the world and South Africa is no exception. Among the landmark events held in South Africa after the end of apartheid was the hosting of the 1995 Rugby World Cup, the 1996 African Cup of Nations, the 1998/9 All-Africa Games, the 2003 Cricket World Cup, and the 2010 FIFA Soccer World Cup ${ }^{\mathrm{TM}}$ (2010 FSWC ${ }^{\mathrm{TM}}$ ) (Swart, 2005; Van der Merwe, 2007; Carlson, 2010; Fourie \& Spronk, 2011). These events highlighted South Africa's enthusiastic participation in the staging of various mega-events (Labuschagne, 2008; Van der Merwe, 2007).

\section{LITERATURE SURVEY}

Since 1990, e-commerce has been growing at an incredible pace and many organisations and individuals have been looking to the interactive multimedia technologies, such as the Web and wireless devices as the future, definitive source of information, goods and communication services (Boone, Kurtz, Mackenzie \& Snow, 2010; Morrison, 2010; Rheem, 2010). User-friendly technology, for example the Internet, search engines, advanced mobile 
devices and online social networks have changed the way people communicate, work and perform commercial activities (Hamid, 2008; Shankar, Inman, Mantrala, Kelley \& Rizley, 2011). Furthermore, the Web provides marketers with tremendous interactive technologies than traditional media whereby interactive control gives users quick access to other information resources through related pages (Boone et al., 2010; Shankar et al., 2011; Trainor, Rapp, Beitelspacher \& Schillewaert, 2011). As consumers use social media, such as Twitter, Facebook, Myspace, YouTube, and LinkedIn for making shopping decisions, promotion through these media has become important (Shankar et al., 2011).

As the use of technology has become increasingly more common, the way many businesses function is also dramatically altered such that organisations that do not keep up with advancement have a tendency to lose out to those that do (Millar et al., 2007; Pea \& Hyun, 2006; Liang, 2010). Increasingly, organisations have begun to find ways to incorporate these new technologies into their promotional campaigns and channel strategies, offering customers different ways to communicate, and receive information and buy goods (Sanyaolu \& Amusat, 2012). The tourism sector like other businesses all over the world is facing rapid changes due to the dynamic evolution of new marketing technologies (Tsiotsou \& Vlachopoulou, 2009). As a result, tourism is in the forefront of Information Communication Technology (ICT) adoption and e-business in the area of e-marketing (e-Business W@ @ch Report, 2006).

Similarly, in today business climate, e-marketing is increasingly regarded as a significant part of marketing practice within the majority of various sectors, including sport mega-events (Krishnamurthy, 2006; Gide \& Shams, 2011; Sharifi, Moghadam, Zamanian, O'dinSayyadi \& Shojaheydari, 2011). The emergence of e-marketing technologies, as an electronic medium of marketing tool or marketing channel increasingly offers new opportunities and enhanced competitiveness to organisations, including sport organisation bodies (Hamid, 2008; Gide \& Shams, 2011; Trainor et al., 2011). A growing trend in recent years has been that sport mega-events are increasingly delivered through a variety of platforms, such as personal websites, mobile phone communication, and the social media like Twitter, Facebook, Blogs, YouTube, and Myspace (George, 2008; Volkmer, 2009; Hutchins \& Mikosza, 2010; Rheem, 2010; Finlay, 2011). Advances in the use of these technologies, therefore, have changed the way through which sport services can be delivered to consumers and clients (O’Beirne \& Stoney, 2004).

The Google, YouTube, debates on Myspace.com, cellular phones, iPads and iPhones, for example, have enabled consumers to watch sport games interactively, and this has been encouraged through social networking sites (Volkmer, 2009; Ratten \& Ratten, 2011). All these developments, in the coverage of sport mega-events, serve to reveal the passions that surround sport in new and creative ways (Boyle, 2009). Furthermore, the proliferation of digital cameras and mobile phones with video capturing, has also led to a new phenomenon of 'home-made' videos being posted on the web along with the rise of Twitter being used by sport fans and sport players (Boyle, 2009; Zagnoli \& Radicchi, 2008). As a result, new applications of live streamed sports and new services like the provision of information through SMS and Multimedia Messaging Service (MMS) create new prospects for increasing both personal and mediated attendance of sport mega-event games (Panagiotopoulou, 2007).

With the advent and widespread use of new digital technologies and computing technology, e-marketing is increasingly employed at nearly every stage of sport events, from the preparatory sessions to the scheduling of events and the dissemination of event information via the Web (Rheem, 2010; Finlay, 2011; Theodoraki, 2011). It became apparent from the previous sport mega-events studied since 2000, namely, the Sydney 2000 Olympic Games, the Korea-Japan 2002 FIFA Soccer World Cup ${ }^{\text {TM }}$, the Athens 2004 Olympic Games, Germany 2006 FIFA Soccer World Cup ${ }^{\mathrm{TM}}$, Beijing 2008 Summer Olympic Games, and the Vancouver 2010 Winter Olympic Games, that sport marketers could utilise e-marketing tools to address the consumers of mega-events as these tools have the ability to reach wide and differentiated sport target markets.

During the Beijing 2008 Summer Olympic Games, for example, thousands of individuals took digital photographs and uploaded them to Flickr, sent e-mails and text messages, made Olympics-related entries on blogs and websites, posted to bulletin and discussion boards (Hutchins \& Mikosza, 2010). The consumers also used Skype and accounted for the Olympic experience via text, image and sound on their Facebook, MySpace and Bebo profiles and prompted YouTube videos by using the key words like '2008 Olympics', most of which were not on the official Olympic channel (Hutchins \& Mikosza, 2010; Finlay, 2011). The assumption is that the e-marketing lessons learnt 
from these international previous sport mega-events could provide some key strategic e-marketing guidelines that can be applied to the hosting of future sport mega-events, such as the $2010 \mathrm{FSWC}^{\mathrm{TM}}$.

Although much literature is published on sport mega-events, there are a limited number of studies in the literature that focuses on the optimal usage or effective utilisation of e-marketing in sport mega-events. Historically, studies on sport mega-events such as Kasimati, 2003; Horne, 2004; Kim \& Pertick, 2005; Preuss, 2007; Allmers \& Maennig, 2009; Bresler, 2011; Fourie \& Spronk, 2011, have primarily examined the economic advantages and economic legacies related to the hosting of such mega-events. From an analysis of the literature, it appears as if what is available is widely scattered and case-specific information on how TV, broadcasters and the Web-based technologies have been used mainly for the coverage of the Olympic Games and the FSWC ${ }^{\mathrm{TM}}$ (Maennig \& Du Plessis, 2007:14; O’Reilly \& Lyberger, 2008; Carlson, 2010; Liang, 2010; Sealy \& Wickens, 2008; Finlay, 2011; Ritchie, 2011). Based on an extensive evaluation of the literature, all indications are that academic literature on the application of e-commerce and e-marketing to tourism sport mega-events is lacking. Against this background the 2010 FSWC $^{\mathrm{TM}}$ held in South Africa, is investigated to determine the optimal usage of e-marketing in sport megaevents.

\section{OBJECTIVES OF THIS STUDY}

The research objectives of this study were explicitly formulated as:

- $\quad$ To examine and investigate the role that e-marketing may have when planning, organising and marketing sport mega-events, with reference to the 2010 FSWC $^{\mathrm{TM}}$;

- $\quad$ To determine whether or not e-marketing is a key tool for the strategic marketing of sport mega-events; and

- To develop a conceptual framework for the optimal usage of e-marketing in sport mega-events.

\section{METHODOLOGY}

\section{Research Approach}

The qualitative research design was used to determine and examine the role and usage of e-marketing strategies and tools in mega-events with reference to the $2010 \mathrm{FSWC}^{\mathrm{TM}}$. An in-depth, semi-structured interview strategy was applied to this study. Furthermore, an in-depth interview strategy was chosen to enable the researcher to collect the primary data relating to the problem under investigation. According to Peräkylä (2008), the researcher can reach areas that would otherwise remain inaccessible as well as gain access to people's subjective experiences and attitudes through the use of in-depth interviews.

The in-depth, semi-structured interview strategy was applied in this study because of its flexibility in permitting the researcher to fully explore all the factors that underpin the participant's answers, reasons, feelings, opinions and beliefs and its ability to allow the responses to be fully probed and explored (Legard et al., 2006; Veal, 2006). To this effect, the closed questions yielded results of a quantitative nature and the open-ended questions produced responses of a more qualitative nature.

\section{Research Procedure}

The information about the target population was gathered prior to the process of designing the in-depth interview instrument. During the design of the interview instrument, a series of drafts were produced and these were critically examined until the final version was produced. During this process, a number of guidelines provided by Kvale and Brinkmann (2009), such as the relevance of questions to participants, clarity and avoidance of complex questions were considered when particular questions were assessed. In addition, efforts were also made to ensure that only questions related to the study objectives were asked.

Careful consideration was given to what the study wanted to achieve and this ultimately informed the formulation and phrasing of the survey questions and the avoidance of any ambiguity, which could cause misunderstanding, confusion and invalid responses. Fundamental to this survey was an approach that permitted 
respondents to provide testimony based on case studies from their own experience of having been involved in the marketing and e-marketing of South African sport mega-events. The final version of the interview instrument was therefore kept tighter in terms of providing face-to-face or telephonic contact interview platforms. In addition, the finalised in-depth interview instrument also contained a section for any other comments and/or suggestions regarding the e-marketing of sport mega-events with reference to the $2010 \mathrm{FSWC}^{\mathrm{TM}}$ in particular.

\section{Population}

The in-depth interview survey tools were e-mailed to selected potential respondents across the nine South African host cities for the 2010 FSWC $^{\mathrm{TM}}$, namely, Cape Town, Durban (eThekweni), Johannesburg, Bloemfontein (Mangaung), Tshwane (Pretoria), Rustenburg, Port Elizabeth (Nelson Mandela Metropolis), Polokwane, and Nelspruit (Mbombela), prior to when the actual interview would take place. Figure 1 displays the host cities for the 2010 FSWC $^{\mathrm{TM}}$ from which the selected potential respondents were identified.

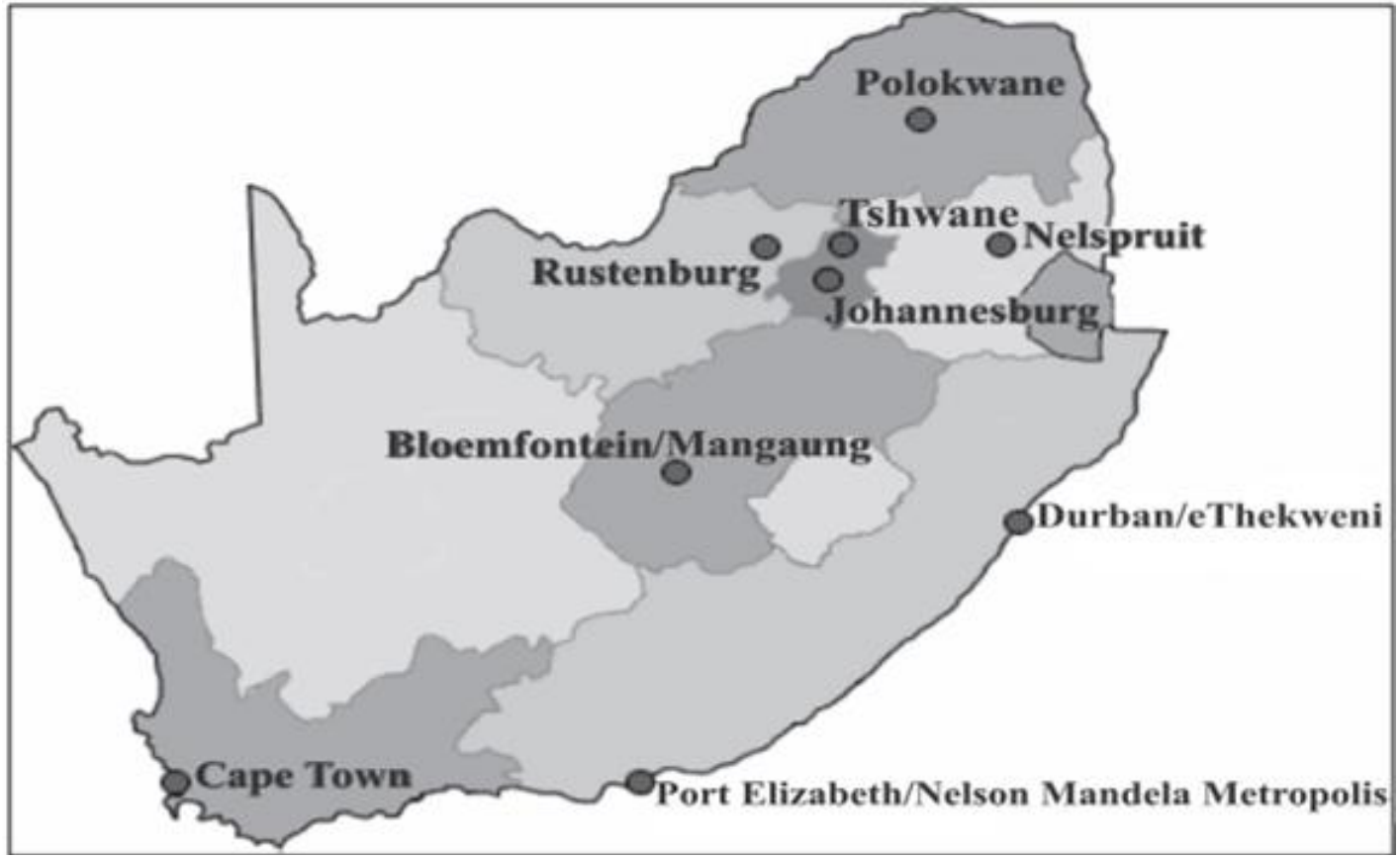

Figure 1: South African Host Cities For The 2010 FIFA Soccer World Cup ${ }^{\mathrm{tm}}$ (Campbell \& Phago, 2008:28)

\section{Sample}

In this study, it was impossible to use probability sampling methods in which all individuals or units in the population have an equal chance of being chosen. Essentially, the non-probability sampling method was used, that is, snowball sampling, which involves asking each respondent or group of respondents to refer the researcher to other respondents (Neergaard, 2007; Merriam, 2009; Wejnert \& Heckathorn, 2011). It was possible to identify a sample of 39 respondents with whom 21 interviews were conducted prior to the $2010 \mathrm{FSWC}^{\mathrm{TM}}$ and 18 later, that is, post-2010 FSWC FM $^{\mathrm{TM}}$.

Since the sample was not based on probability sampling methods designed to ensure a representative sample from the wider community of potential respondents, the responses may be somewhat biased and not representative of that wider community. However, the sample was thought to be fairly typical of the wider population of interest and it was also anticipated that it was drawn from people appropriately qualified to yield insights and an in-depth understanding of the usage of e-marketing strategies and tools for sport mega-events, such as to the $2010 \mathrm{FSWC}^{\mathrm{TM}}$. 
It can be seen from Figure 2 that the population sample size of 39 respondents consisted of individuals drawn from the National, Provincial and Local governments, the umbrella tourism private sector bodies from within South Africa. The sample drawn was of individuals who are managers, directors of the $2010 \mathrm{FSWC}^{\mathrm{TM}}$, events coordinators, researchers from Destination Marketing Organisations (DMOs), senior members of the National and Provincial Tourism Organisations, and the South African Local Organising Committee (SALOC) for the 2010 FSWC $^{\mathrm{TM}}$. Furthermore, the respondents' profile included individuals with expert knowledge; special experience, involvement, and competence in coordination and marketing sport mega-events in South Africa.

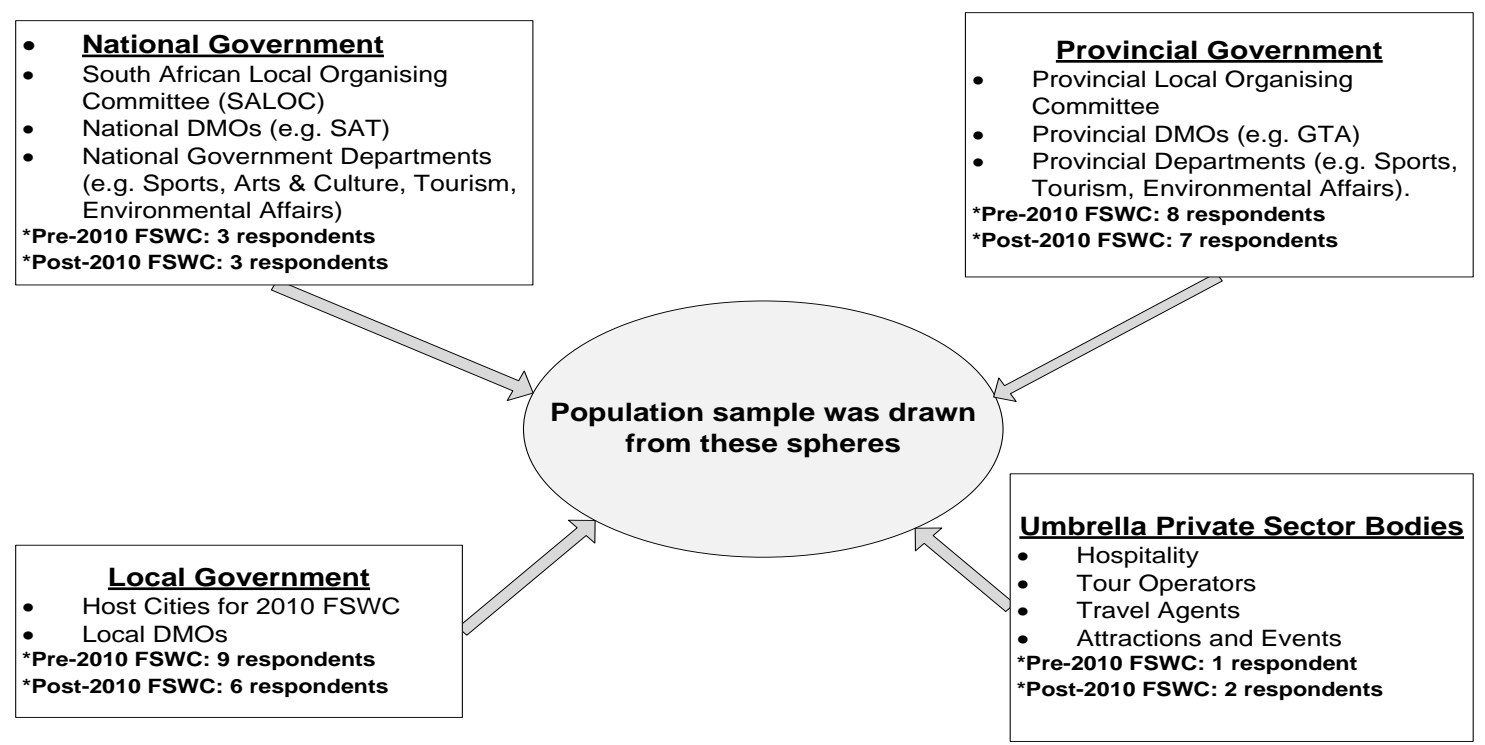

Figure 2: The Four Sectors In South Africa From Which The Sample Was Drawn

The conclusion drawn from the sample profile was that the respondents' responses gave a valuable range of information and insights, because they are experts and decision-makers in organising and marketing of sport megaevents, such as the $2010 \mathrm{FSWC}^{\mathrm{TM}}$. Saturation was achieved as the responses became very repetitive.

\section{Data Collection}

The pre- and post-2010 event interviews that were conducted were of two types, namely, face-to-face and telephonic interviews. In the case of face-to-face interviews, the interviews took place at respondents' venue, that is, where the host cities were in close proximity to the researcher's place of abode, namely Gauteng Province. Due to logistical reasons, the telephonic interviews were conducted with respondents in the host cities considered to be far away from the researcher's place of abode, namely, Cape Town, Port Elizabeth, Durban, Bloemfontein, Polokwane and Nelspruit. Using telephonic interviews was seen to be cost effective, in terms of both time and avoidance of expensive travelling costs to these cities.

Pre-event interviews were conducted for the purpose of determining the intended e-marketing usage for the 2010 FSWC $^{\mathrm{TM}}$, while post-event interviews were conducted to obtain data regarding the actual e-marketing of the event. The main purpose of having interviews with the same respondents during the post-event interviews was to check, verify and confirm whether the respondents interviewed during the pre-event interviews managed to apply the e-marketing strategies and tools they had indicated they would be using for marketing and e-marketing of the $2010 \mathrm{FSWC}^{\mathrm{TM}}$. In addition, the post-event interviews were intended to determine whether there were any other marketing tools and techniques used by the organisers to market the $2010 \mathrm{FSWC}^{\mathrm{TM}}$, besides those mentioned by the respondents during the pre-event interviews. 


\section{Data Analysis}

Qualitative data analysis is a means to explain or make sense of the inquiry by eliciting meaning from the data in a systematic, comprehensive and rigorous manner and, therefore, interpreting and theorising that data (Henning et al., 2004). For this study, data collection and analysis took place simultaneously. This type of analysis as Merriam (2009) states enables the researcher to learn much about the contextual variables from the data gathered. All audio-recorded in-depth interviews were transcribed while the manually completed interview questionnaires were also checked for verifying responses. For this paper, data analysis was based only on 18 in-depth interviews conducted during post-2010 FSWC ${ }^{\mathrm{TM}}$. As Marshall and Rossman (2006) suggest, identification of salient themes, recurring ideas and patterns of belief that links people and settings together were generated during the data compilation process. Essentially, eight themes for the data collected were generated during the designing of the interview instrument. Therefore, the researcher searched for internal convergence and external divergence, because Glaser and Strauss (1967) and Spence et al. (2003) maintain that this help to uncover patterns and themes evident in the setting and points of views expressed by the respondents.

Furthermore, as Glaser \& Strauss (1967) suggest, the data was analysed and interpreted in a systematic way because this provides social researchers with relevant predictions, explanations, interpretations and applications. In presenting the research results, illustrations were used and in some instances the illustrations are accompanied by figures to present data as evidence for the conclusions that were drawn, and the researcher also quoted directly from the interviews.

\section{FINDINGS}

\section{The Actual Use of E-Marketing}

Eighteen respondents confirmed that they had used e-marketing during the $2010 \mathrm{FSWC}^{\mathrm{TM}}$. Therefore, emarketing was actually used during the $2010 \mathrm{FSWC}^{\mathrm{TM}}$ as intended. In confirmation of this, two of the respondents stated:

"We used all of the above. Everything mentioned in the concept of e-marketing above. We participated in every single one of them (that is, internet and its related technologies and features (e.g. the Web, e-mails, social networking, online video, Web 2.0, Travel 2.0, tagging, wikis, web blogs, podcasts)..." (Q3.2: Respondent 2); and

"We continuously used Website, Mobisite (real-life documentary-style short videos for web purposes), Facebook, Twitter, Search Engine advertising, and E-mail” (Q3.2: Respondent 7).

\section{The Actual E-Marketing Tools Used}

It can be seen from Figure 3, that different e-marketing tools, such as websites, social media and mobile technology were actually used during the $2010 \mathrm{FSWC}^{\mathrm{TM}}$ as intended. This was confirmed by two respondents who stated:

"For the first time the 2010 FIFA Soccer World Cup was watched on a cell phone. South Africa needs to have capacity to take advantages of e-marketing opportunities, and the key challenge will be to sustain that" (Theme 6: Respondent 2); and

“... We constantly engage with people in sports to remind them how successful we were in hosting the 2010 FIFA Soccer World Cup ${ }^{T M}$ and therefore we have the capacity or South Africa has the capacity in that respect..." (Theme 6: Respondent 11).

It can also be seen from Figure 3 that additional e-marketing tools, over and above those intended, were used during the 2010 FSWC $^{\mathrm{TM}}$, such as Tagging, Wikis and Travel 2.0. As shown in Figure 3, little mention is made of having used mobile technology for e-marketing the $2010 \mathrm{FSWC}^{\mathrm{TM}}$ event, as only two respondents stated that they had actually used cellular phones during this event. It is surprising, because Cole (2009:1) states that "the 2010 
FSWC $^{\mathrm{TM}}$ was to be a showcase for mobile content and applications, because a global mobile operator, namely, Cole Solutions LLC was among the flagship sponsors for the tournament". Furthermore, Cole (2009) highlights the fact that during the 2010 FSWC $^{\mathrm{TM}}$ event, "mobile users of iPhone, BlackBerry and Android, as well as the iPad were kept up-to-date with all the latest sport news related to the 2010 event in ten languages including Russian, Chinese and Arabic".

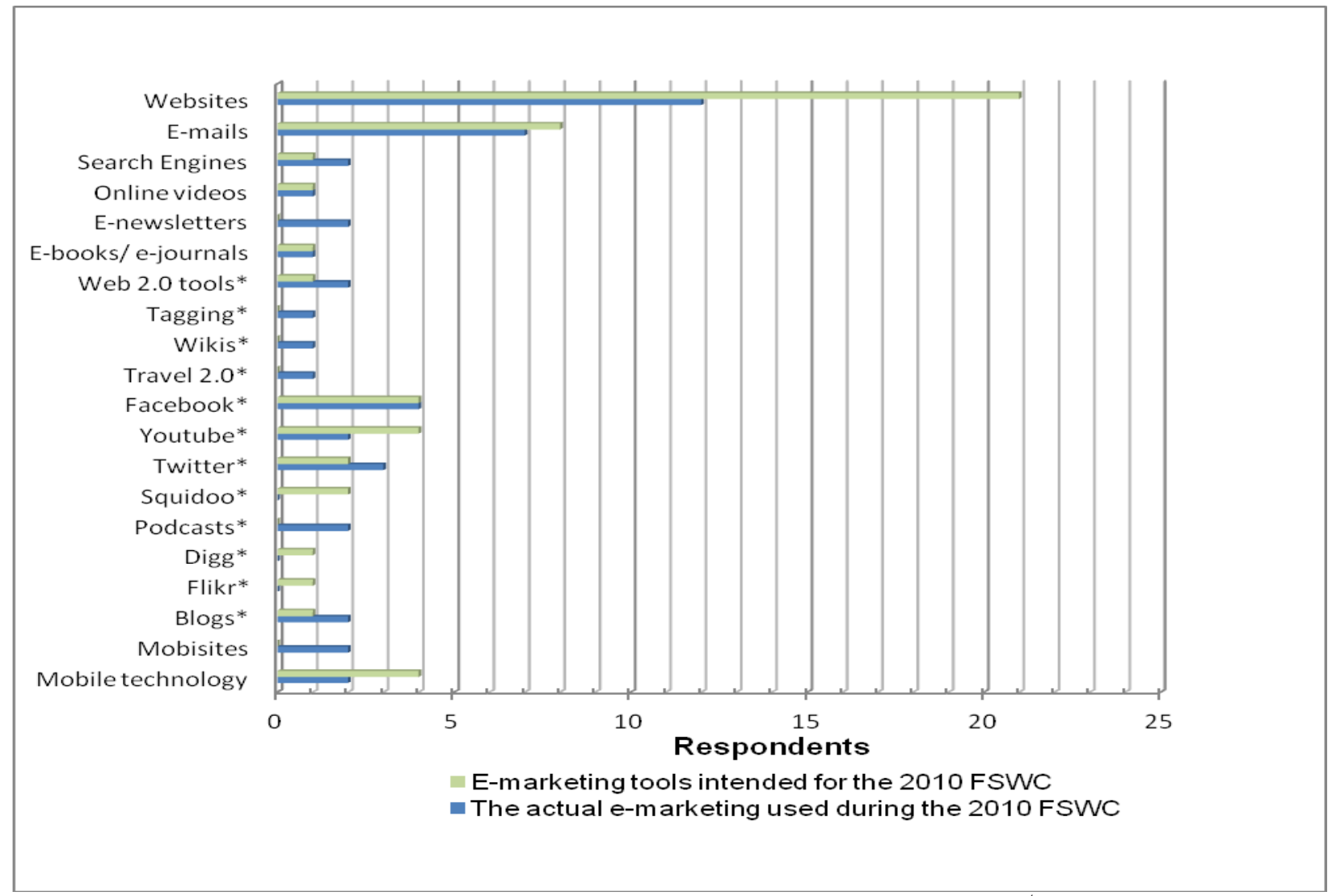

Figure 3: E-Marketing Tools Used In The 2010 FIFA Soccer World Cup ${ }^{\text {tm }}$

In addition, it is interesting to note that e-marketing tools were used simultaneously with the traditional media during the $2010 \mathrm{FSWC}^{\mathrm{TM}}$. Two respondents stated the following:

“...In terms of marketing, we did not ignore traditional platforms like TV and Print. We used the online platforms to interact with our consumers and we used traditional platforms to drive consumers to our website" (Q3.2: Respondent 1); and

"We used the website, cell phones, television and radio for the purpose of bringing about updates regarding the City's state of readiness and preparedness" (Q3.2: Respondent 15).

These statements confirm that an integrated e-marketing approach is critical for future sport mega-events.

\section{The Actual Purpose for Which E-Marketing Was Used}

As shown in Figure 4, nine respondents actually used e-marketing to place advertisements related to the $2010 \mathrm{FSWC}^{\mathrm{TM}}$, less than the 15 who intended to use e-marketing for a similar purpose. It can also be seen from Figure 4, that ten respondents actually used e-marketing to promote South Africa as the host for the $2010 \mathrm{FSWC}^{\mathrm{TM}}$, while four used it to provide information on tourism services. 
The figure also shows that e-marketing was used to do online bookings, although at a minimal rate. However, the responses show that the respondents had different opinions regarding the performance of e-marketing in this regard. For example, ten respondents felt that e-marketing tools enabled the marketers of the $2010 \mathrm{FSWC}^{\mathrm{TM}}$ to successfully promote South Africa globally as a tourism destination as was intended.



Figure 4: The Actual Purpose For What E-Marketing Was Used In The 2010 FIFA Soccer World Cup ${ }^{\text {tm }}$

One of these respondents stated:

"...The research after the 2010 event shows that more than $90 \%$ of people that came to the event in South Africa want to come back to South Africa, and we know that $80 \%$ of the people that came here had great experiences and would tell other people how South Africa is...For example, we never used to operate in Spain but Spain has now become an important market for South Africa...we managed to change the perceptions of people globally that South Africa is more than a destination or place of violence and poverty but that South Africa has other things as well" (Q4.1: Respondent 1).

What is highlighted in this statement is that e-marketing of the $2010 \mathrm{FSWC}^{\mathrm{TM}}$ actually raised South Africa, as the host destination, to international prominence because South Africa was capable of attracting international audiences.

Two respondents were not really happy about the performance of e-marketing tools in achieving the purpose for which they were actually used during the $2010 \mathrm{FSWC}^{\mathrm{TM}}$. One respondent stated:

"We did use the e-marketing tools although not in full swing as expected, due to infrastructural challenges" (Q3.2: Respondent 14); and another commented:

"...The greatest weaknesses in my assessment are some of the value chain players who seemed to wake up rather too late to the need for proper planning. We also did not package the information according to the specific market needs due to poor Customer Relations Management (CRM) processes so that we could do a better market segmentation exercise in understanding the soccer fans from specific parts of the world; especially areas that are not very familiar with our destination" (Q3.2: Respondent 9).

The conclusion drawn was that e-marketing was actually used for different purposes than was intended during the $2010 \mathrm{FSWC}^{\mathrm{TM}}$. However, some concerns were raised that highlighted the fact that e-marketing was not fully utilised as intended. 


\section{The Actual Stages at Which E-Marketing Tools Were Used}

Ten respondents confirmed that they used e-marketing tools consistently or 'throughout' the $2010 \mathrm{FSWC}^{\mathrm{TM}}$ event, while eight did not use e-marketing tools at the same momentum during the 2010 FSWC $^{\mathrm{TM}}$ as they did once the event started.

\section{The Actual E-Marketing Strategy During the 2010 FIFA Soccer World Cup ${ }^{\mathrm{TM}}$}

As shown in Figure 5, nine respondents stated that their organisations had a dedicated e-marketing strategy, two stated that e-marketing was not a stand-alone strategy, but was part of the entire marketing strategy, two (Q3.3: Respondent 6 and 12) said that there were no e-marketing initiatives for the 2010 event and five reported that emarketing was done on an ad-hoc basis.

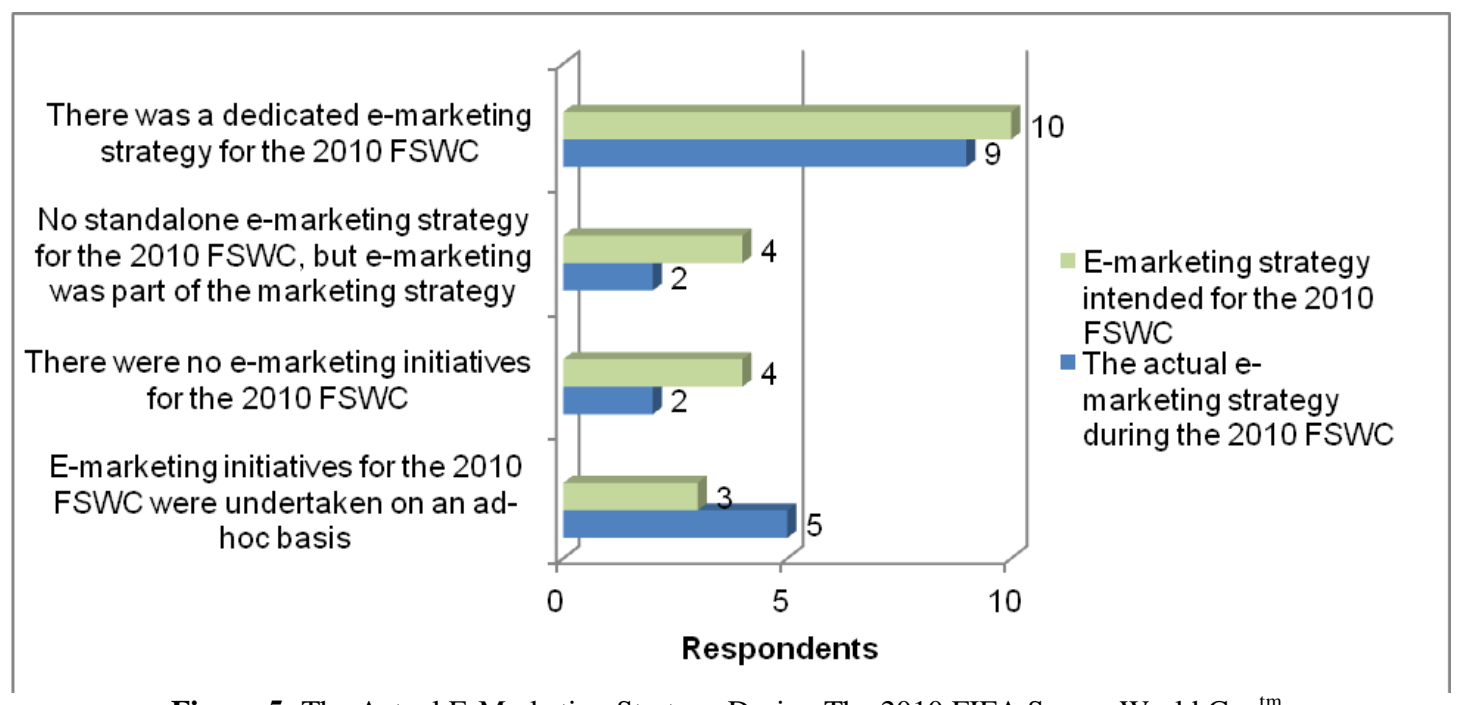

Figure 5: The Actual E-Marketing Strategy During The 2010 FIFA Soccer World Cup ${ }^{\mathrm{tm}}$

The assumption made from these findings is that the lack of common e-marketing initiatives undertaken during the 2010 FSWC $^{\mathrm{TM}}$ could have been attributed to the lack of a clear-cut e-marketing strategy undertaken by the various organisations involved in e-marketing the event. This could also possibly be due to the fact that some organisations had a global marketing strategy rather than a stand-alone e-marketing strategy. Nevertheless, half of the organisations which were involved in the e-marketing of the $2010 \mathrm{FSWC}^{\mathrm{TM}}$ had a dedicated e-marketing strategy. This confirms that an e-marketing strategy was used as a driving force to ensure that e-marketing was used during the $2010 \mathrm{FSWC}^{\mathrm{TM}}$ as intended.

In today's business, an organisational strategic action plan is critical to move any organisation into an attractive business position and to build sustainable competitive advantage (Nik, 2008). Therefore, what seems to be important in the e-marketing of international sport mega-events is a dedicated e-marketing strategy that outlines the e-marketing plans, the e-marketing personnel and the e-marketing budget required for a successful outcome of these events. One respondent confirmed this by stating:

"We have an e-marketing strategy and we actually came up with a specific campaign specifically for the 2010 Soccer World Cup" (Q3.3: Respondent 2).

\section{The Actual Use of E-Marketing Tools with Other Stakeholders}

Sixteen respondents confirmed that they used e-marketing tools together with a wide range of other industry stakeholders during the $2010 \mathrm{FSWC}^{\mathrm{TM}}$. One respondent reported not having used e-marketing tools in collaboration with other industry stakeholders, while one respondent did not provide an answer to this question. 
The findings reveal that partnerships with strategic allies are critical in the e-marketing environment for sport mega-events. A Director of Tourism, who was responsible for Promotion and Development of Tourism in one of the host cities stated:

"Sport mega-events link departments because they enhance new ways of communication amongst stakeholders. During these events the hosts must show that they keep pace with technological change..." (Theme 6: Respondent 4); while the Acting Senior Manager for the 2010 Legacy and Flagships working for the Local Government stated:

"The success of hosting the best World Cup in the history of the 2010 FIFA Soccer World Cup was very much alive as a result of partnerships with stakeholders..." (Q3.4: Respondent 15).

The outcomes regarding the usage of e-marketing tools in collaboration with other industry stakeholders during the $2010 \mathrm{FSWC}^{\mathrm{TM}}$ indicate that it was successful as was intended.

\section{The Actual Expenditure on E-Marketing Initiatives}

The range of expenditure for e-marketing initiatives identified during the $2010 \mathrm{FSWC}^{\mathrm{TM}}$, were similar to those envisaged, that is, from R 100000 to R 600 000, R 600000 to R 20 million and R 20 million to R 300 million. Four respondents presented accurate expenditure estimates for the e-marketing initiatives during the $2010 \mathrm{FSWC}^{\mathrm{TM}}$, which, in turn, fell within the identified range of expenditure. Five respondents stated that it was difficult to mention the actual expenditure for e-marketing initiatives during the 2010 event. For example, one of these respondents stated that:

"It will not be a true reflection of the exact figures given because certain partnerships mitigated the cost. For example, the SABC were the official partners in the World Cup, which paved ways for host cities to forge partnerships with local based SABC radio stations. Then one can imagine the kind of airtime that the partnerships bailed out" (Q3.5: Respondents 15).

Only one respondent was not willing to disclose the e-marketing expenditure during the $2010 \mathrm{FSWC}^{\mathrm{TM}}$ because such information was believed to be 'confidential'.

During the $2010 \mathrm{FSWC}^{\mathrm{TM}}$, it became apparent that some of the organisations which were involved in the emarketing of this event did not have a specific e-marketing budget. This was perhaps due to the fact that there was no dedicated e-marketing strategy for the $2010 \mathrm{FSWC}^{\mathrm{TM}}$ within such organisations or to the fact that e-marketing initiatives relating to the $2010 \mathrm{FSWC}^{\mathrm{TM}}$ were incorporated into the entire organisational marketing strategy. The fact that there was a budget for e-marketing initiatives in some of the organisations involved in the e-marketing of the $2010 \mathrm{FSWC}^{\mathrm{TM}}$ could be attributed to these organisations having a stand-alone e-marketing strategy for the 2010 FSWC $^{\mathrm{TM}}$.

The sport marketers who were involved in the e-marketing of the $2010 \mathrm{FSWC}^{\mathrm{TM}}$ gave estimates on the expenditure for e-marketing initiatives related to the event. It is also interesting to note that eight respondents stated that minimal costs were incurred on e-marketing initiatives during the 2010 FSWC $^{\mathrm{TM}}$. Two of these respondents confirmed this by making statements that:

"The micro-site was managed in-house, thus it did not incur any expenditure" (Q3.5: Respondent 12); and

"It is not expensive to use e-mails and Internet as we have systems in place” (Q3.5: Respondent 14).

These statements reiterated what has already been highlighted in the literature that there is a need for a greater usage of online media when e-marketing is used for future sport mega-events, because e-marketing is by all indications more cost effective than traditional marketing. Furthermore, online media is perceived to be growing rapidly since e-marketing tools are cheaper. Indeed, this confirms that e-marketing is one of the potential technologies to be applied to the marketing of future sport mega-events as has been discussed in the literature review. It is, however, also imperative for sport marketers to assess the costs associated with implementing an emarketing plan for sport mega-events. 


\title{
The Challenges of E-Marketing the 2010 FIFA Soccer World Cup ${ }^{\mathrm{TM}}$
}

\author{
Inappropriate Timing When Using E-Marketing Tools
}

The failure to design e-marketing plans on time was stated as one of the critical factors to be considered when using e-marketing for future sport mega-events. The $2010 \mathrm{FSWC}^{\mathrm{TM}}$ seemed not to be an exception because one respondent highlighted this problem by stating:

"Initially when we started with e-marketing there were problems in getting the site up on time, in making it userfriendly, and in getting people to interact with the site. Every campaign requires a large amount of awareness and I think in the beginning the awareness was not that high. But, when everything was up and running that is when people started interacting with the site" (Q3.6: Respondent 1).

Although little mention was made of the time factor as being one of the e-marketing challenges experienced during the $2010 \mathrm{FSWC}^{\mathrm{TM}}$, this could perhaps be one of the issues to be considered when using emarketing for future events. Failing to set up e-marketing sites on time, in one instance cited during the 2010 FSWC $^{\mathrm{TM}}$, could be attributed to several factors reported by the respondents. For example, three respondents cited the lack of appropriate e-marketing knowledge amongst the users as one of the causes of inappropriate timing when using e-marketing tools. Four respondents mentioned the absence of planned e-marketing strategies and the lack of dedicated and skilled e-marketing personnel to provide support and maintenance of e-marketing technology as emarketing challenges emerging from the $2010 \mathrm{FSWC}^{\mathrm{TM}}$.

These are critical factors to consider carefully when using e-marketing in future sport mega-events, because e-marketing managers need to be well informed about e-marketing planning processes. In addition, it is important for event marketers to gather up-to-date e-marketing knowledge throughout in order to be able to manage the emarketing planning process aimed at satisfying identified customers' desires and needs.

\section{The Problem Of Access To E-Marketing Tools}

Four respondents stated that the accessibility of e-marketing tools was a problem encountered during the 2010 FSWC $^{\mathrm{TM}}$, particularly in the rural areas where challenges existed in respect of access to the Internet. Therefore, a clear message is that sport marketers who intend to use e-marketing tools in future major sport events should not assume that everybody has access to e-marketing tools. Sport marketers of future sport mega-events must ensure that e-marketing tools are made more accessible to the public before e-marketing technology can be used in sport megaevents.

\section{Infrastructural And Technical Network Challenges}

The infrastructural and technical network challenges were raised by four respondents as one of the emarketing challenges arising during the $2010 \mathrm{FSWC}^{\mathrm{TM}}$. One of these respondents highlighted the fact that:

"The only real problem experienced was seeing that Africa was far from being mobile on the desktop Internet. So, we had got to shift a lot of our campaign and give them a mobile enabled desktop Internet. That was the big problem or challenge we faced. So, the whole 'one size fits all' approach doesn't work in Africa because it works in first world countries. So, you can't use flashes in Africa because a lot of African audiences don't have mobile phones compatible with flashes. So, we created special mobile phones because of Africa” (Q3.6: Respondents 2).

It became evident from the research findings that relevant infrastructure and reliable technical networks to handle recent e-marketing tools must first be put in place before e-marketing technology can be used in future sport mega-events. 
Financial Constraints Related To E-Marketing Of The 2010 FIFA Soccer World Cup ${ }^{\text {tm }}$

The financial risks and the allocation of a specific e-marketing budget are mentioned in literature as one of the critical issues to be performed when using e-marketing for future sport mega-events. As such, three respondents stated that e-marketing initiatives during the $2010 \mathrm{FSWC}^{\mathrm{TM}}$ were constrained by limited funds. One of these respondents, who worked as a Brand Manager for a provincial tourism agency stated:

"Financial constraints affected our e-marketing advertising campaign" (Q3.6: Respondent 3) and another respondent, who worked as the $2010 \mathrm{FWC}^{\mathrm{TM}}$ Coordinator in one of the host cities, stated: "The challenge that we are experiencing is around the issue of accessibility and I think that still remains: and affordability of etool marketing for the broader community to access some of the opportunities that might come with hosting of this event, especially the poorest of the poor...Sometimes they had to go and pay $R 20.00$ for the Internet which they could add in purchasing the ticket with" (Q3.6: Respondent 11).

It is evident that the financial constraints related to e-marketing initiatives during the $2010 \mathrm{FSWC}^{\mathrm{TM}}$ should not be underestimated. According to Nik (2008), developing and implementing e-marketing programmes can be expensive, because costs are linked to the design and integration of software, internet access, technology support, website operation and maintenance as well as training. It could be stated that e-marketing initiatives for the 2010 FSWC $^{\mathrm{TM}}$ were constrained by limited funds for purchasing the e-marketing tools, for providing the Internet infrastructure and hiring the relevant e-marketing personnel. It is, therefore, important that sport event marketers develop a performance evaluation matrix to assess the costs associated with e-marketing initiatives in order to ultimately ensure that the e-marketing benefits outweigh the costs and create greater value when e-marketing is used for sport mega-events.

\section{Political Challenges That Affected The Usage Of E-Marketing}

The hosting of sport mega-events is associated with political risks or challenges. According to Theodoraki (2011), local politicians and business leaders may apply pressure to the event organisers for the reorientation of event preparations in line with their personal agenda. It appears that e-marketing of the $2010 \mathrm{FSWC}^{\mathrm{TM}}$, as with other sport mega-events previously held in South Africa, was also hindered by political challenges. This fact was confirmed by two respondents $(\mathrm{Q} 3.6$ : Respondents 9,16$)$ who stated:

"Indecisiveness by the political principals in availing the special project budgets to fund the relevant projects including the usage of e-marketing. Procurement processes also become a drag in a scenario where everything gets off to a lazy start and suddenly starts moving at an alarming speed" (Q3.6: Respondent 9); and

"Yes, there were challenges because we were unable to have all the information on the web due to FIFA's strict rules on the use of some of the trademarks or words" (Q3.6: Respondent 16).

Therefore, it is of great significance that sport marketers of future sport mega-events must be aware of political challenges because there are often attempts by local politicians to hijack event preparations to fit their personal agenda and this may have an impact on the e-marketing initiatives related to major sport events. Sport event marketers should always be prepared to manage the political challenges that may hinder optimal usage of emarketing in sport mega-events.

\section{Lack Of Collaboration And Cooperation Amongst The Stakeholders}

The findings on the actual usage of e-marketing tools with other industry stakeholders during the 2010 FSWC $^{\mathrm{TM}}$ revealed that there was collaboration with the marketing initiatives of other industries during this period. Only two respondents stated that there was a lack of collaboration and cooperation amongst stakeholders involved in the e-marketing of the 2010 FSWC $^{\mathrm{TM}}$. Their statements are reflected below:

"Yes, trying to get sponsors and stakeholders like FIFA to work together takes a very long time” (Q3.6: Respondent 15); and A Senior Manager for Tourism Marketing stated: 
"Not really, however, one of the challenges would be the silo-effect which results to uncoordinated marketing strides especially from institutions of government that is supposed to be combining resources for the same course. Host cities have their own campaigns, Tourism Authorities their own, Provincial Government has its 2010 organising units, all these reasons are aimed to promote the 2010, and however, their endeavours are not cocoordinated" (Q3.6: Respondent 16).

According to these respondents, the agendas of the various stakeholders shape their views about the event's ultimate success or failure. As a result, when using e-marketing for future sport mega-events, it is of paramount importance that partnerships with supporting stakeholders are taken into account in terms of the power they hold over the resources, such as financial and physical resources as well as the intangible aspects, such as goodwill and branding. Sport marketers should strive to create synergies amongst stakeholders who will then benefit collectively from the e-marketing of sport mega-events.

Although it is reported in the literature that updating information about products or services, security and privacy invasion of users' information on a regular basis remains a constant drawback of e-marketing (Hume \& Sullivan, 2008; Linh, 2010), surprisingly, not one of the respondents mentioned these factors as e-marketing challenges encountered during the $2010 \mathrm{FSWC}^{\mathrm{TM}}$. Of great importance is that marketers must expect to encounter emarketing challenges like these when e-marketing is used in sport mega-events and they should always be prepared to handle them successfully.

\section{MANAGERIAL APPLICATIONS FOR SPORT MEGA-EVENTS}

Building on the literature studied, the local and international case studies that were evaluated and the results of the empirical research, the theoretical and practical contributions of the study is a strategic e-marketing framework for future sport mega-events. This framework is presented in Figure 6.

The fundamental components of the proposed e-marketing framework for the optimal usage of e-marketing in sport mega-events were identified as the enabling environment which comprises the macro-and-micro environments, the technological environment, the key stakeholders who have to be identified and motivated to work together and the e-marketing strategy for sport mega-events. In terms of this proposed e-marketing framework, emarketing technology would be optimally used in sport mega-events only if the conditions indicated in the 11 CSFs identified for e-marketing sport mega-events are met.

The CSFs for the e-marketing of sport mega-events, therefore, serve as guidelines for the implementation of the proposed conceptual e-marketing framework. 


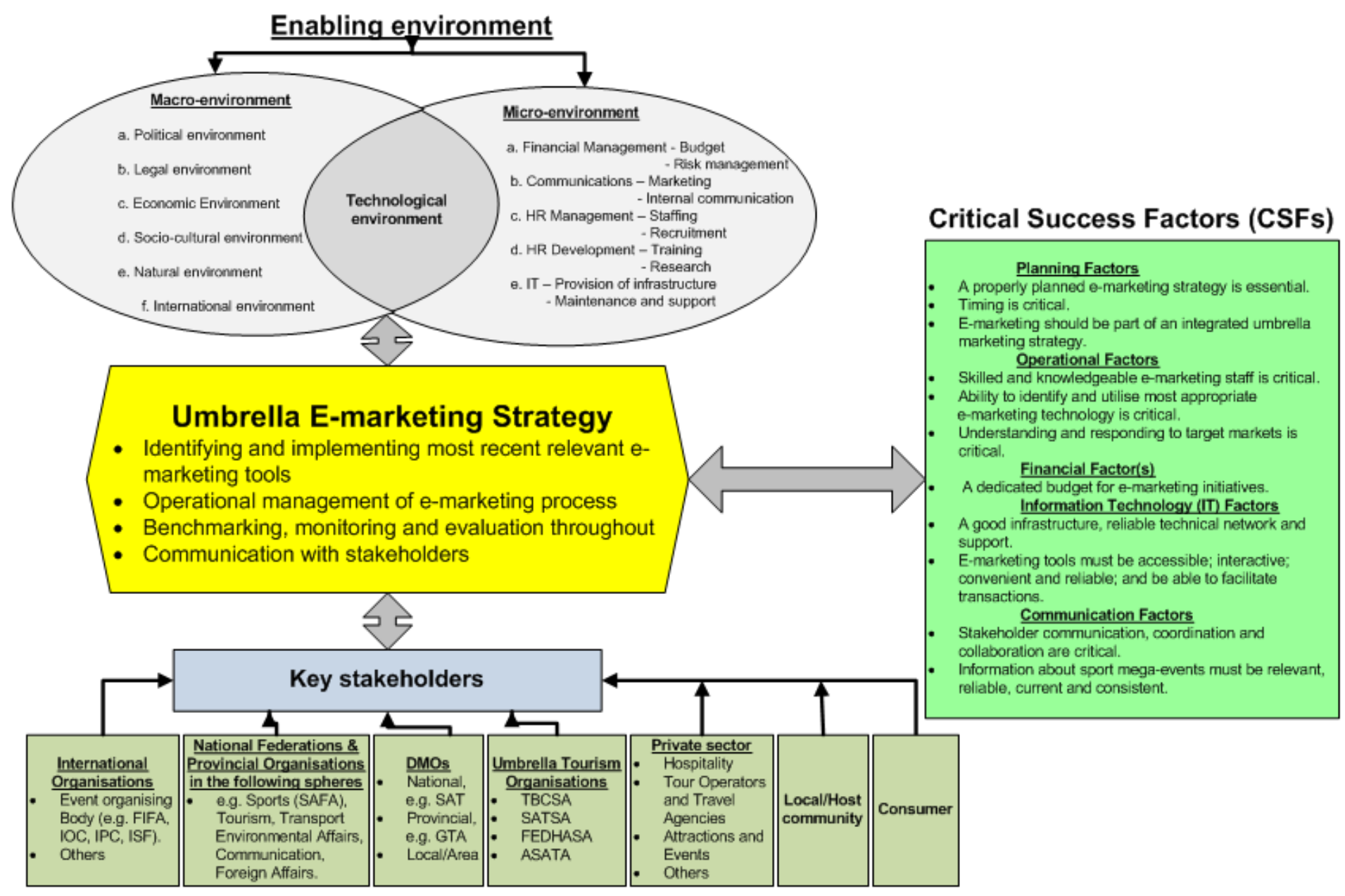

Figure 6: Framework For The Optimal Usage Of E-Marketing In Sport Mega-Events 
From the proposed e-marketing framework, the overarching e-marketing strategy is seen and regarded as the engine that is critical for driving e-marketing initiatives related to sport mega-events, while at the same time enabling sport marketers to respond to the macro-environmental factors that impact on e-marketing initiatives for sport mega-events and to keep pace with the technological developments related to e-marketing. It is envisaged that with the proper implementation of the proposed strategic e-marketing framework, the sport marketers for future host destinations may be able to optimally use e-marketing technology for sport mega-events.

With regard to the implementation of the proposed e-marketing framework illustrated in Figure 6, the planning factors would be the starting point of the process, followed by the correct placement of the operational factors essential for the usage of e-marketing technology in sport mega-events. Thereafter, the financial factors, including an approved budget generated specifically for e-marketing initiatives relating to sport mega-events, would make it possible for sport marketers to establish the reliable infrastructural network required for the operation of emarketing technology and strategies.

It is assumed that once the conditions applicable to the IT factors are met, then e-marketing technology may be used optimally in campaigns surrounding sport mega-events through the implementation of the identified communication CSFs.

\section{CONCLUSION}

In order to optimally use e-marketing in sport mega-events, it has become evident from the research findings that an understanding of the potential role of e-marketing in sport mega-events is critical. Throughout this study, the researchers examined, investigated and produced a coherent assessment of the e-marketing applications in sport mega-events. The findings derived from the empirical research identified the purposes for which e-marketing is used in sport mega-events and confirmed the Critical Success Factors (CSFs) relating to e-marketing sport megaevents.

In order for e-marketing to be optimally used in sport mega-events, there are certain fundamental aspects that have to be in place before the sport mega-event can commence. As a result, the contribution of this study to the existing body of knowledge is the theory, generated from the research findings on the strategic e-marketing framework, which conceptualises perspectives for the effective utilisation of e-marketing tools in sport mega-events.

\section{AUTHORS' INFORMATION}

Dr. Paul S. Radikonyana. Paul Shimane Radikonyana is currently a Specialist System Analyst for GIS Applications within the Transversal BI/GIS division at the State Information Technology Agency (SITA) since October 2009. His interest in tourism lies within Destination Marketing, Environment and Development, Ecotourism, and Sustainable Tourism Development.

Prof. Ernie Heath. Ernie Heath is a Professor and Head of the Department of Tourism Management at the University of Pretoria and also served on the United Nations World Tourism Organization (UNWTO) Education Council. He has extensive tourism experience, particularly in the spheres of community tourism development, strategic tourism management and destination marketing.

Dr. Felicité Fairer-Wessels. Felicité is an associate professor in the Department of Marketing Management at the University of Pretoria, South Africa. Her interests are Teaching and Research in Ecotourism, Sustainable Tourism and Event Management.

Prof. J.J. Prinsloo. Hein Prinsloo is the Marketing Professor at the Graduate School of Business and Government Leadership, North-West University, South Africa. His research focuses on both Sport Marketing and Adventure Tourism.

Prof. Theuns G. Pelser. Theuns Pelser is professor, Dean and Head of School, Graduate School of Business and Leadership, University KwaZulu-Natal. He holds a PhD in Strategic Management from the Potchefstroom 
University. He teaches Strategy, and supervises masters and doctoral students. He has published widely in scholarly journals, attended and delivered conference papers. E-mail: theuns.pelser@gmail.com (contact author)

\section{REFERENCES}

Allmers, S. \& Maennig, W. (2009). Economic impacts of the FIFA Soccer World Cups in France 1998, Germany 2006, and outlook for South Africa 2010. Eastern Economic Journal, 35(4) 500-519.

Boone, L.E., Kurtz, D.E., Mackenzie, H.F. \& Snow, K. (2010). Contemporary marketing (2 ${ }^{\text {nd }}$ ed.). Ontario: Nelson Education Ltd.

Boyle, R. (2009). Why sport matters: New challenges in the Digital Age (online article). Centre d'Estudis Olimpics UAB. [http://olympicstudies.uab.es/pdf/boyle.pdf]. Retrieved on 2 December 2010.

Bresler, N.C. (2011). Tourist considerations in hosting a mega sport event: 2010 FIFA World Cup in South Africa. South African Journal for Research in Sport, Physical Education and Recreation, 33(2) 17-33.

Campbell, M. \& Phago, K. (2008). The impact of major sporting events on the economy and the people of a Developing Region: The Case of the 2010 FIFA World Cup Tournament. Africa Insight, 38(3) 26-34.

Carlson, A.F. (2010). Small business and the 2010 FIFA World Cup: The use of communication technology in South African micro-enterprise. Unpublished PhD-thesis. Ohio: Scripps College of Communication of Ohio University.

Cole, A. (2009). World Cup 2010 to spur major growth of mobile content and apps market. [http://www. itnewsafica.com/2009/11/ world-cup-2010-to-spur-major-growth-of-mobile- content-and-apps-market]. Retrieved on 4 April 2011.

E-Business W@tch Report. (2006). The European e-Business Report 2006/7 edition: A portrait of e-business in 10 sectors of the EU economy. $5^{\text {th }}$ Synthesis Report of the e-Business W@tch. Luxembourg: European Commission source. [http://www.ebusiness-watch.org]. Retrieved on 2 October 2013.

Finlay, C.J. (2011). Between Leveraging and Legacy: Producing the 2012 London Olympics in a Global New Media Environment. Unpublished PhD-thesis. Pennsylvania: University of Pennsylvania.

Fourie, J. \& Spronk, K. (2011). South African mega-sport events and their impact on tourism. Journal of Sport \& Tourism, 16(1) 75-97.

George, R. (2008). Marketing tourism in South Africa ( $4^{\text {th }}$ ed.). Cape Town: Oxford University Press.

Gide, E. \& Shams, S.M.R. (2011). The role of Web-based promotion on the development of a relationship marketing model to enable sustainable growth. Procedia Computer Science, 3(1) 1060-1073.

Glaser, B.G. \& Strauss, A.L. (1967). The discovery of grounded theory: Strategies for qualitative research. New York: Aldine de Gruyter.

Hachleitner, B. \& Manzenreiter, W. (2010). The Euro 2008 bonanza: mega-events, economic pretensions and the sports-media business alliance. Soccer \& Society, 11(6) 843-853.

Hamid, N.R.A. (2008). Consumers' behaviour towards Internet technology and Internet marketing tools. International Journal of Communications. 3(2) 195-204.

Henning, E., Van Rensburg, W. \& Smit, B. (2004). Finding your way in qualitative research. Pretoria: Van Schaik Publishers.

Horne, J. (2004). The global game of football: the 2002 World Cup and regional development in Japan. Third World Quarterly, 25(7) 1233-1244.

Hume, M. \& Sullivan, G.S. (2008). Enhancing the experience creating service opportunities using mobile phone technology in museums. London Journal of Tourism, Sport and Creative Industries, 1(2) 3-20.

Hutchins, B. \& Mikosza, J. (2010). The Web 2.0 Olympics athlete blogging, social networking and policy contradictions at the 2008 Beijing Games. Convergence: The International Journal of Research into New Media Technologies, 16(3) 278-297.

Kasimati, E. (2003). Economic aspects and the Summer Olympics: A review of related research. International Journal of Tourism Research, 5(6) 433-444.

Kavetsos, G. \& Szymanski, S. (2010). National well-being and international sports events. Journal of Economic Psychology, 31 158-171.

Kim, S.S. \& Petrick, J.F. (2005): Residents' perceptions on impacts of the FIFA 2002 World Cup: the case of Seoul as a host city. Tourism Management, 26(1) 25-38.

Konstantaki, M. \& Wickens, E. (2010). Residents' perceptions of environmental and security issues at the 2012 London Olympic Games. Journal of Sport and Tourism, 15(4) 337-357. 
Krishnamurthy, S. (2006). Introducing E-MARKPLAN: A practical methodology to plan e-marketing activities. Business Horizons, 49(1) 51-60.

Kvale, S. \& Brinkmann, S. (2009). Interviews: Learning the craft of qualitative research interviewing. Thousand Oaks: Sage Publications.

Labuschagne, P. (2008). The impact of sport on nation building: A critical analysis of South Africa and the 2010 FIFA World Cup. Africa Insight. 38(3) 3-14.

Legard, R., Keegan, J. \& Ward, K. (2006). In-depth interviews, In J. Ritchie, \& J. Lewis (Eds.), Qualitative research practice: A guide for social science and researchers. London: Sage Publications.

Liang, L. (2010). Control and Spontaneity in the Beijing Olympic Theatre - The Making of a Global Sports Media Event. Unpublished PhD-thesis. Illinois: North-Western University.

Linh, L.H.T. (2010). E-marketing channels: The digital influence on small sized businesses. Unpublished BA-thesis. Finland: Mikkeli University of Applied Sciences.

Maennig, W. \& Du Plessis, S. (2007). World Cup 2010: South African economic perspectives and policy challenges informed by the experience of Germany 2006. Contemporary Economic Policy, 25(4) 578-590.

Marshall, C. \& Rossman, G.B. (2006). Designing qualitative research. Thousand Oaks: Sage Publications.

Merriam, S.B. (2009). Qualitative research and case study applications in education: Revised and expanded from case study research in education. San Francisco: Jossey-Bass Publishers.

Millar, M.L., Schrier, T.R. \& Kim, E.K. (2007). WiFi availability and accessibility as stated on hotel websites. Hospitality Management. [http://repository.usfca.edu/hosp/1]. Retrieved on 19 September 2013.

Morrison, A.M. (2010). Hospitality and travel marketing ( $4^{\text {th }}$ ed.). Australia: Delmar Cengage Learning.

Neergaard, H. (2007). Sampling in entrepreneurial settings, In H. Neergaard, \& J.P. Ulhoi (Eds.), Handbook of qualitative research methods in entrepreneurship. Cheltenham: Edward Elgar Publishing.

Nik, T.M. (2008). Achieving superior results from the mature market through e-marketing planning. Unpublished PhD-thesis. Minneapolis: NorthCentral University.

O'Beirne, C. \& Stoney, S. (2004). Information technology and management information systems in sport, In J. Beech, \& S. Chadwick (Eds.), The business of sport management. Harlow: Pearson Education.

O'Reilly, N. \& Lyberger, M., McCarthy, L. \& Séguin, L. (2008). Mega-special-event promotions and intent to purchase: A longitudinal analysis of the Super Bowl. Journal of Sport Management, 22 392-409.

Pan, B. \& Li, X.R. (2011). The long tail of destination image and online marketing. Annals of Tourism Research, 38(1) $132-152$.

Panagiotopoulou, R. (2007). New trends in communication of mega sporting events. [http://amrc.cuc.edu.cn/ data/upload/download/PDF/07/07-13.pdf]. Retrieved on 16 April 2010.

Pea, J.H. \& Hyun, J.S. (2006). Technology advancement strategy on patronage decisions: The role of switching costs in high-technology markets. Omega. 31(1) 19-27.

Peräkylä, A. (2008). Analyzing talk and text, In N.K. Denzin, \& Y.S. Lincoln (Eds.), Collecting and interpreting qualitative materials. Los Angeles: Sage Publications.

Pillay, U. \& Bass, O. (2008). Mega-events as a response to poverty reduction: The 2010 FIFA World Cup and its urban development implications. Urban Forum, 19(3) 329-346.

Preuss, H. (2007). FIFA World Cup 2006 and its legacy on tourism, In R. Conrady, \& M. Buck, (Eds.), Trends and issues in global tourism. Berlin: Springer.

Ratten, V. \& Ratten, H. (2011). International sport marketing: practical and future research implications. Journal of Business \& Industrial Marketing, 26(8) 614-620.

Rheem, C. (2010). What's next for European online travel? In R. Conrady, \& M. Buck, (Eds.), Trends and issues in global tourism. Berlin: Springer.

Ritchie, L. (2011). Social media enter the stadium: A case study on the political economy of media at the 2010 Winter Olympics. Unpublished MA-thesis. Canada: Royal Roads University

Sanyaolu, T.O. \& Amusat, I.O. (2012). The relevance of e-marketing on economic development, In O.B. Ogundiran, T. Ojuade, S. Afuape, B.O. Isola, A. Akintayo, \& P. Zannu, (Eds.), Proceedings of 2012 National Conference on National Security and Economic Development for Democratic Consolidation. Lagos: School of Management and Business Studies, Lagos State Polytechnic, 353-364.

Sealy, W. \& Wickens, E. (2010). The potential impact of mega sport media on the travel decision-making process and destination choice. The case of Portugal and Euro 2004. Journal of Tourism Marketing, 24(2-3) 127137.

Shankar, V., Inman, J.J., Mantrala, M., Kelley, E. \& Rizley, R. (2011). Innovations in shopper marketing: Current 
insights and future research issues. Journal of Retailing, 87(1) 829-842.

Spence, L.; Ritchie, J. \& O’Connor, W. (2003). Analysis; practices, principles and processes, In J. Ritchie, J. Lewis (Eds.), Qualitative research practice. London: Sage Publications.

Swart, K. (2005). Strategic planning - implications for the bidding of sport events in South Africa. Journal of Sport \& Tourism, 10(1) 37-46.

Theodoraki, E. (2011). Event management, In L. Robinson, \& D. Palmer (Eds.), Managing voluntary sport organisations. London: Routledge Taylor \& Francis Group.

Trainor, K.J., Rapp, A., Beitelspacher, L.S. \& Schillewaert, N. (2011). Integrating information technology and marketing: An examination of the drivers and outcomes of e-marketing capability. Industrial Marketing Management. 40(1) 162-174.

Tsiotsou, R.H. \& Vlachopoulou, M. (2009). Understanding the effects of market orientation and e-marketing on service performance. Marketing Intelligence and Planning. 29(2) 141-155.

Van der Merwe, J. (2007). Political analysis of South Africa's hosting of the Rugby and Cricket World Cups: Lessons for the 2010 Football World Cup and beyond? Politikon, 34(1) 67-81.

Veal, A.J. (2006). Research methods for leisure and tourism: A practical guide ( ${ }^{\text {rd }}$ ed.). Harlow: Prentice Hall.

Volkmer, I. (2009). Conflict-related media events and cultures of proximity. Media, War and Conflict, 1(1) 90-98.

Neergaard, H. (2007). Sampling in entrepreneurial settings, In H. Neergaard, \& J.P. Ulhoi (Eds.), Handbook of qualitative research methods in entrepreneurship. Cheltenham: Edward Elgar Publishing Limited.

Wejnert, C. \& Heckathorn, D. (2011). Respondent-driven sampling: Operational procedures, evaluation of estimates, and topics for future research, In M. Williams, \& W.P. Vogt (Eds.), The Sage handbook of innovation in social research methods. London: Sage Publications Limited.

Zagnoli, P. \& Radicchi, E. (2008). Real and virtual sport events in marketing industrial products. Unpublished MAthesis. Italy: University of Florence. 